\title{
A complete study of Doxazosin characterization
}

\author{
Itamar Luís Gonçalves ${ }^{\mathrm{a}}$, Mariana Maier Gaelzer ${ }^{\mathrm{b}}$, Gabriel Oliveira de Azambuja ${ }^{\mathrm{a}}$, Christianne Gazzana Salbego ${ }^{\mathrm{b}}$, Vera \\ Lucia Eifler-Lima ${ }^{\mathrm{a}} *$ \\ ${ }^{a}$ Laboratório de Síntese Orgânica Medicinal/LaSOM, Programa de Pós-Graduação em Ciências \\ Farmacêuticas/PPGCF, Universidade Federal do Rio Grande do Sul, \\ Av. Ipiranga 2752, 90610-000 Porto Alegre-RS, Brazil \\ ${ }^{b}$ Programa de Pós-Graduação em Ciências Biológicas: Bioquímica, Instituto de Ciências Básicas da Saúde, \\ Universidade Federal do Rio Grande do Sul (UFRGS), Porto Alegre, RS, Brasil \\ * Corresponding author e-mail: veraeifler@ufrgs.br
}

Doxazosin is an important drug used to treat hypertension and prostatic hyperplasia. An enantiomeric $(R) /(S)$ doxazosin mesylate mixture was complete characterized by NMR and additionally FT-IR spectroscopy techniques. Different NMR experiments were performed, such as APT, HSQC, and HMBC in order to confirm the NMR signals assignments. All the hydrogens and most of carbons atoms were assigned. In this context, the results reported here, consists in important information for identification and quality control of doxazosin mesylate.

Keywords: doxazosin; NMR; FT-IR; signals assignment.

\section{Introduction}

Doxazosin ((4-(4-amino-6,7-dimethoxyquinazolin2-yl)piperazin-1-yl)(2,3-dihydrobenzo[b][1,4]dioxin-2yl)methanone) is a long-acting selective $\alpha_{1}$-adrenergic antagonist, employed in treatment for arterial hypertension (1) and benign prostatic hyperplasia (2). Pfizer introduced tablets of doxazosin mesylate in US market in 1995 (3). The action of doxazosin in hypertension is associated with their effect in reducing total peripheral resistance by selective postsynaptic $\alpha_{1}$ blockade, without affecting cardiac output, and heart rate (1). Furthermore recent findings suggested that doxazosin may become a new pharmacotherapy alternative for the treatment of gliomas (4).

Advantages of repurposing drugs are the welldefined pharmacokinetics and side effects, and the drug has passed the required toxicity and safety tests with settled protocols and dosing (5). Regarding doxazosin, it is established the drug's antitumoral effects are not related with its $\alpha 1$-adrenoceptor antagonism (6). Due to its physicochemical characteristics, doxazosin is able to permeate the blood-brain barrier (7), and we found the drug presented low neurotoxicity on non-tumor cells (4).

The chemical structure of doxazosin is formed by a quinazoline core A, and a 1,4-benzodioxane core B, linked by a piperazine ring (Figure 1). The quinazoline core linked to piperazine is a very important scaffolding in doxazosin structure, considering that it is ubiquitous in their prazosin and terazosin analogues (8). Despite the importance of this drug in therapeutic use, there are few reports in the literature about their chemical characterization (9), which makes it difficult to control their quality. The existence of spectroscopy data about doxazosin characterization, may be a useful guide for impurities and degradation products identification in doxazosin mesylate. Considering this aspect, we report here the first detailed analysis describing the complete NMR, using bi-dimensional techniques for the characterization of doxazosin mesylate in the racemate form, in which the Infrared spectrum FT-IR was used.

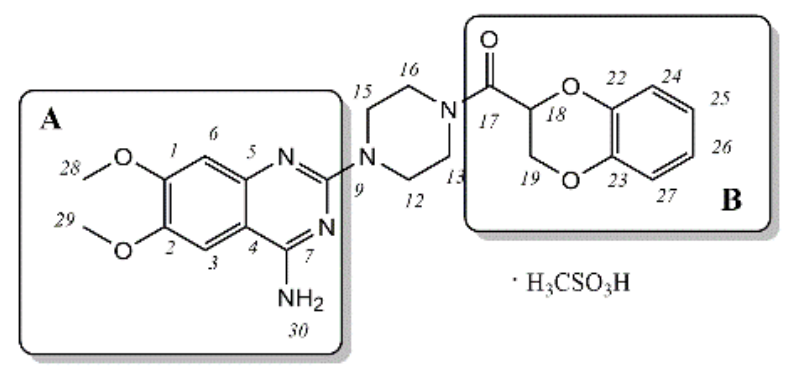

Figure 1 Structure of rac-doxazosin mesylate.

\section{Methodology}

An enantiomeric $(R) /(S)$ doxazosin mesylate mixture, purchased from Nifty Labs PVT LTD, was solubilized in DMSO- $d_{6}(20 \mathrm{mg}$ in $0.5 \mathrm{~mL})$ and the nuclear magnetic resonance spectra $\left({ }^{1} \mathrm{H}\right.$ NMR and ${ }^{13} \mathrm{C}$ NMR) was recorded in a Bruker Ascend spectrometer with standard pulse sequences operating at $400 \mathrm{MHz}$ for ${ }^{1} \mathrm{H}$ NMR and $100 \mathrm{MHz}$ for ${ }^{13} \mathrm{C}$ NMR. Chemical shifts were reported as relative values (ppm) to TMS. 
The NMR multiplicities $s, d, t, q$, and $m$ stand for singlet, doublet, triplet, quartet and multiplet, respectively. The ${ }^{1} \mathrm{H}$ NMR AB systems were presented in the following order: hydrogen a (Ha) the most deshielded and hydrogen $b(\mathrm{Hb})$ the most shielded. For validation of these assignments, theoretical calculations of ${ }^{13} \mathrm{C}$ NMR chemical shifts were performed in a software MestReNova 6.0.2-5475 (MestreLab Research S.L., 2009). FT-IR spectra was recorded in a Perkin Elmer Spectrometer BXII using an ATR probe.

\section{Results and Discussion}

\section{NMR experiments}

The quinazoline ring A (see Figure 1) presents two singlets corresponding the aromatic hydrogens $\mathrm{H}_{3}$ and $\mathrm{H}_{6}$ in $7.24 \mathrm{ppm}$ and $7.65 \mathrm{ppm}$, respectively. In relation to the ring substituents, the two singlets corresponding to methoxy groups $\mathrm{C}_{28}$ and $\mathrm{C}_{29}$ appear in 3.84 and 3.90 ppm and can be interconverted. The two hydrogens linked to nitrogen at $\mathrm{C}_{7}$ produce two individual broad singlets in 8.70 and $8.81 \mathrm{ppm}$. The ${ }^{1} \mathrm{H}$ NMR chemical shifts and signals multiplicities were shown in Figure $\mathbf{2}$ were and summarized in Table $\mathbf{1}$.

The signals corresponding to aromatics $\mathrm{C}_{3}$ and $\mathrm{C}_{6}$ of quinazoline ring appear in, respectively, 99.03 and $104.76 \mathrm{ppm}$ (Figure 3), and these carbons can be correlated between $\mathrm{H}_{3}$ and $\mathrm{H}_{6}$ in HSQC experiment. Between $\mathrm{C}_{3}$ and $\mathrm{C}_{6}$ signals, there is the $\mathrm{C}_{4}$ signal, and its assignment is confirmed by $\mathrm{HMBC}$ spectra, considering its ${ }^{2} \mathrm{~J}$ coupling with $\mathrm{H}_{3}$. The $\mathrm{C}_{1}$ and $\mathrm{C}_{2}$ atoms generated the signals at $155.44 \mathrm{ppm}$ and 146.92 ppm respectively, an characteristic of aromatic quinazoline carbons di-methoxy substituted found in literature (10). The $\mathrm{C}_{9}$ chemical shift (151.39 ppm) was attributed considering that this signal in HMBC experiment has no correlation with hydrogens of quinazoline ring. Additionally, the two methoxyl groups, $\mathrm{C}_{28}$ and $\mathrm{C}_{29}$, substitutions on ring $\mathrm{A}$, produces only one signal at $56.18 \mathrm{ppm}$. Considering the $\mathrm{HMBC}$ analysis the carbons $\mathrm{C}_{4}, \mathrm{C}_{5}$ and $\mathrm{C}_{7}$ were assigned as chemical shifts in 101.66, 135.99 and $161.32 \mathrm{ppm}$ respectively. The ${ }^{13} \mathrm{C}$ NMR chemical shifts and correlations found in HSQC and HMBC spectra can be observed in Table 2, while the NMR bi-dimensional spectra are showed in Figures 4 and $\mathbf{5}$.

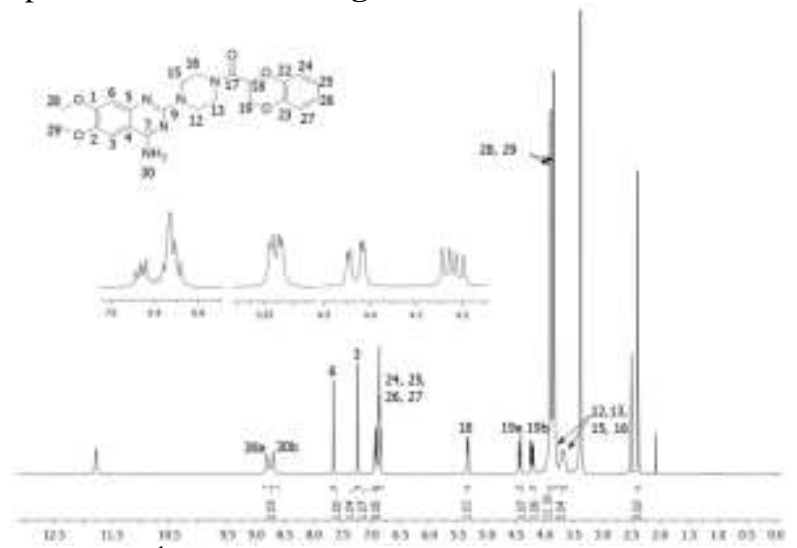

Figure $2{ }^{1} \mathrm{H}$ NMR spectrum $\left(400 \mathrm{MHz}, \mathrm{DMSO}-\mathrm{d}_{6}\right)$ of doxasozin.
Table $1{ }^{1} \mathrm{H}$ NMR data for doxazosin.

\begin{tabular}{|c|c|c|}
\hline$\delta(\mathrm{ppm})$ & Multiplicity & Assignment \\
\hline 3.54 & Multiplet & $\mathrm{H}_{13}, \mathrm{H}_{16}$ \\
\hline 3.99 & Multiplet & $\mathrm{H}_{12}, \mathrm{H}_{15}$ \\
\hline 3.84 & Singlet & $\mathrm{H}_{28}$ or $\mathrm{H}_{29}$ \\
\hline 3.90 & Singlet & $\mathrm{H}_{28}$ or $\mathrm{H}_{29}$ \\
\hline 4.22 & $\begin{array}{l}\text { double duplet } J=11.8 \mathrm{~Hz} \\
6.5 \mathrm{~Hz}\end{array}$ & $\mathrm{H}_{19 \mathrm{~b}}$ \\
\hline 4.43 & $\begin{array}{l}\text { double duplet } J=11.8 \mathrm{~Hz} \text {; } \\
2.5 \mathrm{~Hz}\end{array}$ & $\mathrm{H}_{19 \mathrm{a}}$ \\
\hline 5.33 & $\begin{array}{l}\text { double duplet } J=6.5 \mathrm{~Hz} \text {; } \\
2.5 \mathrm{~Hz}\end{array}$ & $\mathrm{H}_{18}$ \\
\hline $6.83-6.95$ & multiplet & $\mathrm{H}_{24}, \mathrm{H}_{25}, \mathrm{H}_{26} \mathrm{H}_{27}$ \\
\hline 7.24 & singlet & $\mathrm{H}_{3}$ \\
\hline 7.65 & singlet & $\mathrm{H}_{6}$ \\
\hline 8.70 & broad singlet & $\mathrm{N}-\mathrm{H}_{\mathrm{b}}$ \\
\hline 8.81 & broad singlet & $\mathrm{N}-\mathrm{H}_{\mathrm{a}}$ \\
\hline
\end{tabular}

The 1,4-benzodioxane ring $\mathrm{B}$ signals have four aromatic hydrogens $\mathrm{H}_{24}, \mathrm{H}_{25}, \mathrm{H}_{26}, \mathrm{H}_{27}$ that appear in upfield compared to quinazoline. The aromatic hydrogens signal, characteristic of a 1,4-benzodioxane ring $(11,12)$, was non-resolved in the range of 6.83$6.95 \mathrm{ppm}$. The three aliphatic hydrogens generated the signals at between 4 to $6 \mathrm{ppm}$. The diastereotopic hydrogens $\mathrm{H}_{19 \mathrm{a}}$ and $\mathrm{H}_{19 \mathrm{~b}}$ appeared at $4.43 \mathrm{ppm}$ and 4.22 ppm respectively, while the hydrogen $\mathrm{H}_{18}$ linked to chiral carbon $\mathrm{C}_{18}$ produced a double of doublets at 5.33 ppm with $\mathrm{J}_{\mathrm{H} 18 \mathrm{H} 19 \mathrm{~b}}=6.5 \mathrm{~Hz}$ and $\mathrm{J}_{\mathrm{H} 18 \mathrm{H} 19 \mathrm{~b}}=2.5 \mathrm{~Hz}$. The multiplicity of $\mathrm{H} 19 \mathrm{~b}$ presented a double of doublets with $\mathrm{J}_{\mathrm{H} 19 \mathrm{H} 18}=2.5 \mathrm{~Hz}$ and a vicinal coupling $\mathrm{J}_{\mathrm{H} 19 \mathrm{aH} 19 \mathrm{~b}}=11.8 \mathrm{~Hz}$. Due to their spatial disposition, these hydrogens coupling in a different manner with $\mathrm{H}_{18}$, produceding $\mathrm{J}$ values of 6.8 and $2.5 \mathrm{~Hz}$. This coupling between these hydrogens justifies completely the multiplicity of signals presents in $4.22,4.43$ and 5.33 ppm.

In relation to the ${ }^{13} \mathrm{C}$ NMR spectra, the 1,4benzodioxane ring carbons $\mathrm{C}_{18}(\mathrm{CH})$ and $\mathrm{C}_{19}\left(\mathrm{CH}_{2}\right)$ produce the signals at 69.44 and $64.66 \mathrm{ppm}$ respectively, and its assignment can be confirmed in APT and HSQC spectra (Figure 3 and Figure 4). A ${ }^{2} \mathbf{J}$ coupling of $\mathrm{C}_{19}$ with $\mathrm{H}_{18}$, and $\mathrm{C}_{18}$ with $\mathrm{H}_{19 \mathrm{a}}$ and $\mathrm{H}_{19 \mathrm{~b}}$ diasterotopic hydrogens can be also observed in HMBC spectra. The aromatic carbons of 1,4benzodioxane $\left(\mathrm{C}_{24}, \mathrm{C}_{25}, \mathrm{C}_{26}\right.$ and $\left.\mathrm{C}_{27}\right)$ produced four undifferentiated signals between 115 to $120 \mathrm{ppm}$. $\mathrm{C}_{22}$ and $\mathrm{C}_{23}$ carbons produced two signals at 142.84 and $143.06 \mathrm{ppm}$, assignment that can be confirmed by coupling with aromatic hydrogens of 1,4-benzodioxane in HMBC spectra. In $165.27 \mathrm{ppm}$, it is present the only carbonylic carbon of the structure, which has a ${ }^{2} \mathrm{~J}$ with $\mathrm{H}_{18}$ and ${ }^{3} \mathrm{~J}$ coupling with and $\mathrm{H}_{19}$ in HMBC spectra. The analysis of HSQC spectra showed that hydrogens 
$\mathrm{H}_{19 \mathrm{a}}$ and $\mathrm{H}_{19 \mathrm{~b}}$ are linked to the carbon at $64.66 \mathrm{ppm}$ and the $\mathrm{H}_{18}$ with the carbon at $69.44 \mathrm{ppm}$. In addition, it may be verified that methoxy groups $\mathrm{C}_{28}$ and $\mathrm{C}_{29}$ produced only one signal at $56.18 \mathrm{ppm}$.

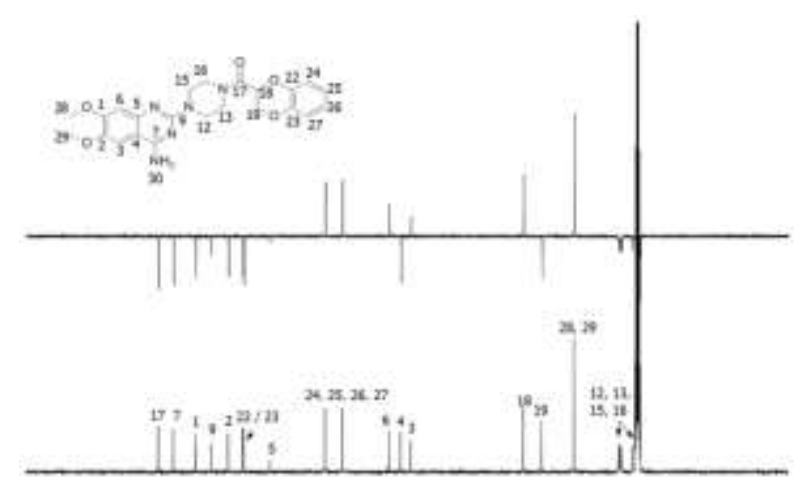

Figure 3 Full and APT ${ }^{13} \mathrm{C}$ NMR spectrum (100 MHz, DMSO- $\mathrm{d}_{6}$ ) of doxazosin mesylate.

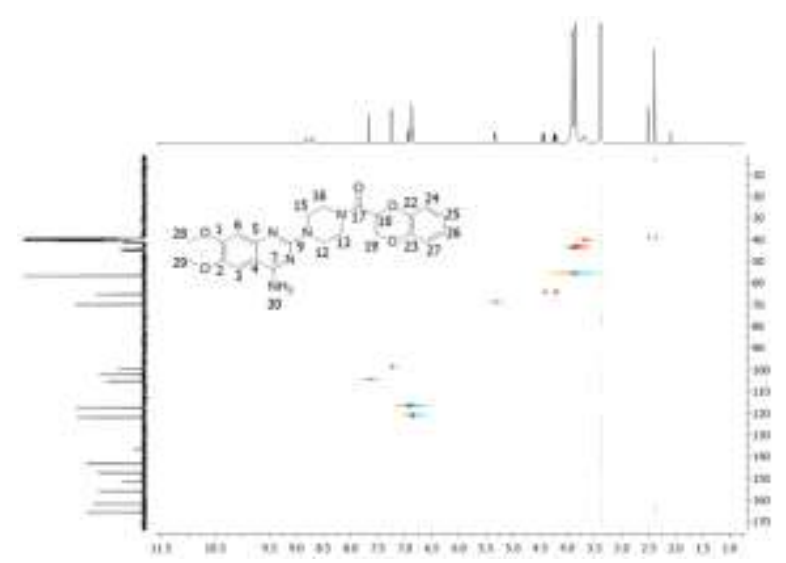

Figure 4 HSQC NMR spectrum of doxasozin mesylate $\left(\mathrm{DMSO}-\mathrm{d}_{6}\right)$.

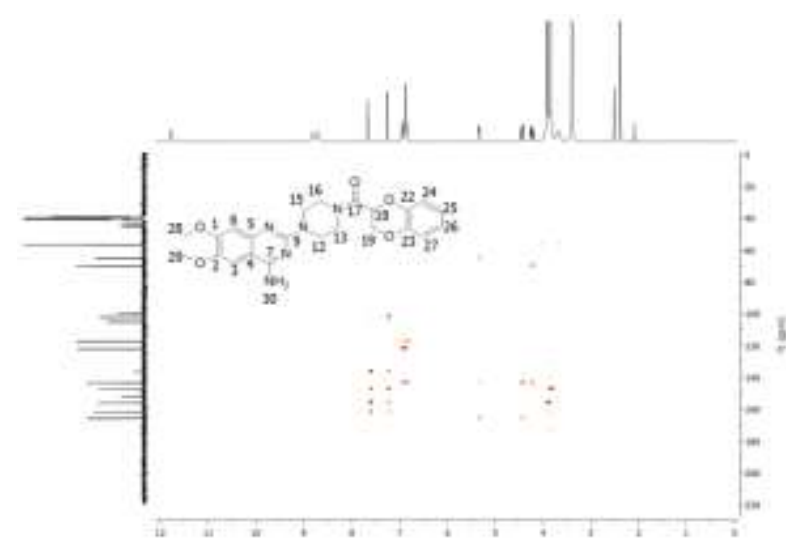

Figure 5 HMBC NMR spectrum of doxasozin mesylate $($ DMSO-d 6 ).
Table $2{ }^{13} \mathrm{C}$ NMR data for doxazosin mesylate and correlation of ${ }^{1} \mathrm{JCH}$ observed in HSQC and ${ }^{\mathrm{n}} \mathrm{JCH}$ in HMBC

\begin{tabular}{|c|c|c|c|}
\hline $\mathrm{C}$ & $\delta{ }^{13} \mathrm{C}(\mathrm{APT})$ & ${ }^{1} \mathrm{~J}_{\mathrm{CH}} \mathrm{HSQC}$ & ${ }^{\mathrm{n}} \mathrm{J}_{\mathrm{CH}} \mathrm{HMBC}$ \\
\hline $\mathrm{C}_{1}$ & 155.44 & - & $\mathrm{H}_{3}, \mathrm{H}_{6,} \mathrm{H}_{28 / 29}$ \\
\hline $\mathrm{C}_{2}$ & 146.92 & - & $\mathrm{H}_{3}, \mathrm{H}_{6,} \mathrm{H}_{28 / 29}$ \\
\hline $\mathrm{C}_{3}$ & 99.03 & $\mathrm{H}_{3}$ & - \\
\hline $\mathrm{C}_{4}$ & 101.66 & - & $\mathrm{H}_{3}$ \\
\hline $\mathrm{C}_{5}$ & 135.99 & - & $\mathrm{H}_{3}, \mathrm{H}_{6}$ \\
\hline $\mathrm{C}_{6}$ & 104.76 & $\mathrm{H}_{6}$ & - \\
\hline $\mathrm{C}_{7}$ & 161.32 & - & $\mathrm{H}_{3}, \mathrm{H}_{6}$ \\
\hline $\mathrm{C}_{9}$ & 151.39 & - & - \\
\hline $\mathrm{C}_{12}, \mathrm{C}_{13}, \mathrm{C}_{15}, \mathrm{C}_{16}$ & $\begin{array}{l}40.80 ; 43.80 ; 44.05 \\
44.46\end{array}$ & $\mathrm{H}_{12}, \mathrm{H}_{13}, \mathrm{H}_{15}, \mathrm{H}_{16}$ & - \\
\hline $\mathrm{C}_{17}$ & 165.28 & - & $\mathrm{H}_{18}, \mathrm{H}_{19 \mathrm{a}}$ \\
\hline $\mathrm{C}_{18}$ & 69.44 & $\mathrm{H}_{18}$ & $\mathrm{H}_{19 b}$ \\
\hline $\mathrm{C}_{19}$ & 64.66 & $\mathrm{H}_{19 \mathrm{a}}, \mathrm{H}_{19 \mathrm{~b}}$ & $\mathrm{H}_{18}$ \\
\hline $\mathrm{C}_{22}, \mathrm{C}_{23}$ & $142.84 ; 143.06$ & - & $\begin{array}{l}\mathrm{H}_{24}, \mathrm{H}_{25}, \mathrm{H}_{26}, \mathrm{H}_{27}, \\
\mathrm{H}_{18}, \mathrm{H}_{19 \mathrm{a}}, \mathrm{H}_{19 \mathrm{~b}},\end{array}$ \\
\hline $\mathrm{C}_{24}, \mathrm{C}_{25}, \mathrm{C}_{26}, \mathrm{C}_{27}$ & $\begin{array}{l}116.92 ; 117.03 ; \\
121.45 ; 121.56\end{array}$ & $\mathrm{H}_{24}, \mathrm{H}_{25}, \mathrm{H}_{26}, \mathrm{H}_{27}$ & $\mathrm{H}_{24}, \mathrm{H}_{25}, \mathrm{H}_{26}, \mathrm{H}_{27}$ \\
\hline $\mathrm{C}_{28}, \mathrm{C}_{29}$ & 56.18 & - & - \\
\hline
\end{tabular}

The piperazine ring presented signals characteristics of the presence of piperazine rings (13, 14) with two multiplets corresponding the two groups of equivalents methylene hydrogens $\mathrm{H}_{12}$ and $\mathrm{H}_{15}$ centered at $3.99 \mathrm{ppm}$, and $\mathrm{H}_{16}$ and $\mathrm{H}_{13}$ at $3.54 \mathrm{ppm}$, which is superposed to singlets from hydrogens of methoxyl 28 and 29 . In relation to the $\mathrm{NMR}{ }^{13} \mathrm{C}$, the four carbons of piperazine linker appeared at 40 to 45 ppm, and due to the similarity of the chemical environment, the assignment of these carbons is very challeging.

Considering that the mesylate salt of doxazosin was analyzed, it is possible to observe that when the methyl group of mesylate is at $2.38 \mathrm{ppm}$ and in $11.60 \mathrm{ppm}$, the acid hydrogen is presented in $\mathrm{H}_{3} \mathrm{CSO}_{3} \mathrm{H}$.

It was found a higher $\mathrm{r}^{2}$ value (0.9915) for correlation between calculated ${ }^{13} \mathrm{C}$ NMR chemical shifts against the experimental values. These results show that carbon chemical shift assignment is adequate for the doxazosin structure, and that prediction can be used as tool for analyze fitting of the assignments. The correlation graph is shown in Figure 6. 


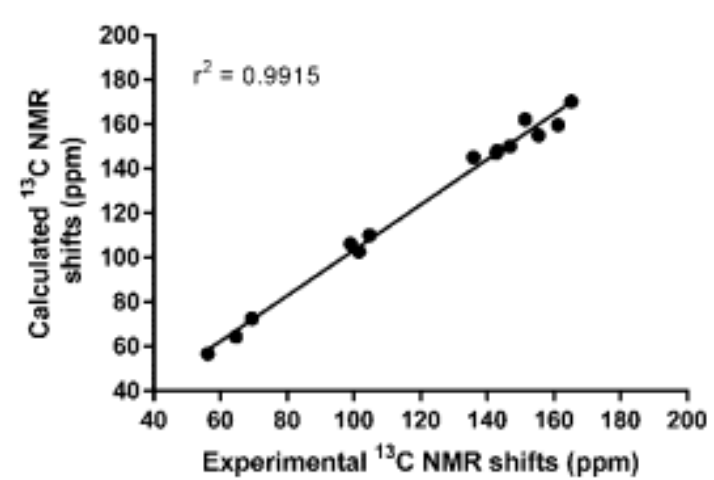

Figure 6 Correlation between calculated and observed NMR shifts. The carbons of piperazine ring and aromatic ring of 1,4-benzodioxane were not included in this analysis. The prediction of chemical shifts was performed using MestReNOva 6.0.2-5475 (MestreLab Research S.L., 2009).

The total assignments of NMR doxazosin may be used in quality control for characterization of impurities from doxazosin synthesis. In doxazosin monography present in British Pharmacopeia are listed 8 possible impurities that may be present in doxazosin (15). In addition United States Pharmacopeia recommends that the doxazosin mesylate production method must be evaluated to determine the potential formation of alkyl mesylates (16). Furthermore, the analysis of NMR spectra also contributes with important informations in relation to the presence degradation impurities.

The total assignments of NMR doxazosin may be used in quality control for characterization of impurities from doxazosin synthesis. In doxazosin monography present in British Pharmacopeia are listed 8 possible impurities that may be present in doxazosin (15). In addition United States Pharmacopeia recommends that the doxazosin mesylate production method must be evaluated to determine the potential formation of alkyl mesylates (16).

Furthermore, the analysis of NMR spectra also contributes with important informations in relation to the presence degradation impurities.

\section{Infrared characterization}

Some stretches are characteristic in doxazosin mesylate FT-IR spectra (Figure 7). The most important band in spectrum of doxazosin occurs in $1632 \mathrm{~cm}^{-1}$ attributed to the presence of tertiary amide band $(\mathrm{C}=\mathrm{O})$. Spectral broad band corresponding to N-H stretching of amine salt is localized at $3159 \mathrm{~cm}^{-1}$. The strong band at 1595.48 can be attributed to N-H bending of aromatic amines. The four C-O bands (stretching) that are presented in doxazosin structure may appear in the region of 1259 to $1168 \mathrm{~cm}^{-1}$.

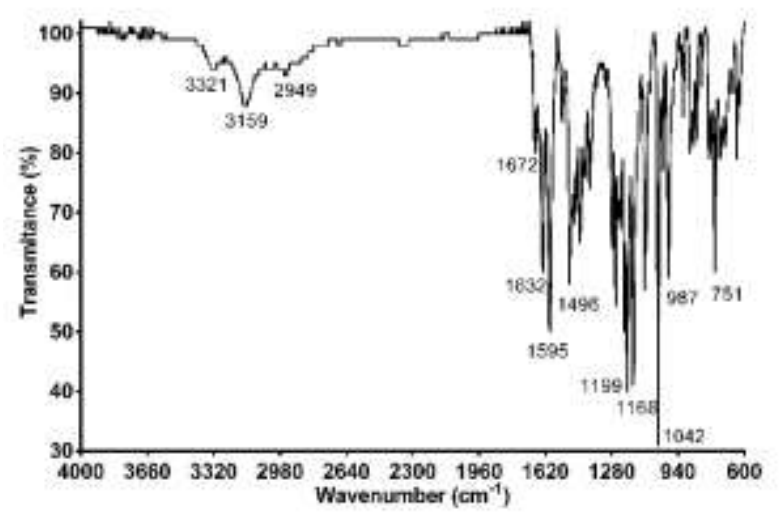

Figure 7 IR spectra (ATR) of doxazosin mesylate.

\section{Conclusions}

The mono- and bi-dimensional ${ }^{1} \mathrm{H}$ and ${ }^{13} \mathrm{C}$ NMR experiments performed here for doxazosin produced a considerable amount of new data. These data may be used as a tool to verify and prove structural modifications in doxazosin for future works. Additionally, the infrared spectra reported here is an important data for an easy doxazosin mesylate identification.

\section{Acknowledgements}

The authors are thankful to CNPq/MCT, INCT-if (Instituto Nacional de Ciência e Tecnologia para Inovação Farmacêutica). The authors ILG and MMG are grateful to CNPq for their scholarship.

\section{References}

1. Wykretowicz, A., Guzik, P., Wysocki, H. Doxazosin in the current treatment of hypertension. Expert opinion on pharmacotherapy. 2008;9(4):625-33.

2. Wilt, T.J., MacDonald, R. Doxazosin in the treatment of benign prostatic hypertrophy: an update. Clinical interventions in aging. 2006;1(4):389.

3. Pfizer. Company History 2017 [cited 2017 20/07/2017]. Available from: http://www.pfizer.com/about/history/all.

4. Gaelzer, M.M., Coelho, B.P., de Quadros, A.H., Hoppe, J.B., Terra, S.R., Guerra, M.C.B., et al. Phosphatidylinositol 3-Kinase/AKT pathway inhibition by doxazosin promotes glioblastoma cells death, upregulation of p53 and triggers low neurotoxicity. PloS one. 2016;11(4):e0154612.

5. Pantziarka, P., Bouche, G., Meheus, L., Sukhatme, V., Sukhatme, V.P., Vikas, P. The repurposing drugs in oncology (ReDO) project. ecancermedicalscience. $2014 ; 8$. 
6. González-Juanatey, J.R., Iglesias, M.J., Alcaide, C., Piñeiro, R., Lago, F. Doxazosin induces apoptosis in cardiomyocytes cultured in vitro by a mechanism that is independent of $\alpha 1$-adrenergic blockade. Circulation. 2003;107(1):127-31.

7. Nikolic, K., Filipic, S., Smoliński, A., Kaliszan, R., Agbaba, D. Partial least square and hierarchical clustering in ADMET modeling: Prediction of bloodbrain barrier permeation of $\alpha$-adrenergic and imidazoline receptor ligands. Journal of Pharmacy \& Pharmaceutical Sciences. 2013;16(4):622-47.

8. Bakshi, M., Ojha, T., Singh, S. Validated specific HPLC methods for determination of prazosin, terazosin and doxazosin in the presence of degradation products formed under ICH-recommended stress conditions. Journal of Pharmaceutical and Biomedical Analysis. 2004;34(1):19-26.

9. Yuan, X-R., Liu, Y-H., Li, R-Y., Chen, X-X. Experimental and theoretical NMR study of (s)doxazosin. Acta Physico-Chimica Sinica. 2008;24(6):1058-62.

10. Loidreau, Y., Besson, T. Microwave-assisted thermal decomposition of formamide: a tool for coupling a pyrimidine ring with an aromatic partner. Tetrahedron. 2011;67(26):4852-7.

11. Rouf, A., Aga, M.A., Kumar, B., Taneja, S.C. A facile approach to chiral 1, 4-benzodioxane toward the syntheses of doxazosin, prosympal, piperoxan, and dibozane. Tetrahedron Letters. 2013;54(48):6420-2.

12. Tsyskovskaia, I., Kandil, M., Beaumier, Y. Synthesis of a New Doxazosin-Related Compound. Synthetic communications. 2007;37(3):447-50.

13. Zhang, L-Y., Wang, B-L., Zhan, Y-Z., Zhang, Y., Zhang, X., Li, Z-M. Synthesis and biological activities of some fluorine- and piperazine-containing 1,2,4triazole thione derivatives. Chinese Chemical Letters. 2016;27(1):163-7.

14. Koester, L.S., Guterres, S.S., Le Roch, M., EiflerLima, V.L., Zuanazzi, J.A., Bassani, V.L. Ofloxacin/ $\beta$ Cyclodextrin Complexation. Drug Development and Industrial Pharmacy. 2001;27(6):533-40.

15. Commission BP. British Pharmacopoeia. London2013.

16. Pharmacopeia U. United States Pharmacopeia. The Standard USA: US Pharmacopeia 1995. 2002. 